\title{
The Problem of Being in Latin America: Approaching the Latin American Ontological sentipensar
}

\section{JUAN CEPEDA H.}

Universidad Santo Tomás, Colombia (juancepeda@usantotomas.edu.co)

In the following, I endeavor to subvert the classical notion of being found in Western philosophy by following the logic of negation found in the work of Rodolfo Kusch. In order to develop a better understanding of cultural feelings as well as appreciate the natural, the rhythmic and the vital in the Latin American context, I propose that we follow the ontological sentipensar. By using this methodological framework, I seek to reveal a sense of being germane to Latin American intercultural philosophy.

Keywords: Ontology; Kusch; Being; Latin America; sentipensar

Introduction

Philosophy in Latin America

has been taking its own path, particularly since 1842 with Alberdi ${ }^{1}$ and even with much greater strength since the middle of the twentieth century.

This philosophizing includes: the history of philosophical ideas, the philosophy of liberation (both in its ethical as in its political lines) ${ }^{2}$, Amerindian philosophies (philosophical indigenous thinking) ${ }^{3}$, intercultural philosophy ${ }^{4}$, philosophies of life (such as the cosmic vitalism) ${ }^{5}$, analogical hermeneutics ${ }^{6}$, logics of denial ${ }^{7}$,

and the ontological sentipensar ${ }^{8}$, among other disciplines that have been arising from Latin America.

Among Latin American thinkers, we have been building an identity

or, at least, a common agenda

to such an extent that it is increasingly possible

Journal of World Philosophies 2 (Summer 2017): 12-27 Copyright (C) 2017 Juan Cepeda H.

e-ISSN: 2474-1795 • http://scholarworks.iu.edu/iupjournals/index.php/jwp• doi: 10.2979/jourworlphil.2.1.02 
to set research projects in motion,

which develop the search, identification,

conceptualization, argumentation and discussion

of notions and categories

proper to Latin American thought,

promoting, in such a way, appropriate methodologies

for those research processes?.

In this text, we look forward to present

the methodological foundations in the base of which

the research on the problem of being advances,

and some evidence of such progress.

The exposition that follows,

as we see,

is presented in short statements

resembling verses

and attempts to come to different senses,

which have already been thickening,

be in talks,

be in dialogues,

be in mambeos, ${ }^{\mathrm{i}}$

or even also in reflections

on documents

that traditional philosophy always offers.

\section{The Question of Being}

The way the ancient Greek people used to think

was wondering about the essence of things:

What is this? What is that?

they would always seek to know

what is

this or that.

Classic Greek language

accounts for this way of wondering,

of understanding,

of being.

To wonder about the Being of things

repeatedly

Mambeo is a South-American indigenous tradition consisting of chewing coca leaves (Translator's note). 
evidences a way of being.

To ask about the Being of things

is an essential asking,

which looks for a knowledge beyond appearance, which seeks to go deep in the phenomenon, which tries to unravel the deep essence of what is asked.

Such a way to ask

ends up taking each question

to a fundamental problem, to a greater problem

and, if you want, to a more general one:

the problem of Being,

just like that:

the Being

as Being,

and nothing else.

To ontology belongs this way of asking

and this way of being.

The Greeks rather liked to reason

in this sense.

If everything we have in front of our eyes

is (is being),

what is it that is?

what is everything that is,

not as something specific being,

but as something that

is

and nothing else?

What is Being?

How to understand the Being?

What sense does [the] Being make?

The Greek language evidences that the Greeks

used to investigate the world

in this direction,

under this horizon.

Probably that is why

among the Greeks emerged those thinkers

who wondered, again and again,

about Being:

Parmenides, Heraclitus,

Plato and Aristotle,

among many others.

Journal of World Philosophies 2 (Summer 2017): 12-27

Copyright (c) 2017 Juan Cepeda H.

e-ISSN: 2474-1795 • http://scholarworks.iu.edu/iupjournals/index.php/jwp• doi: 10.2979/jourworlphil.2.1.02 
But, although the Greeks asked

so explicitly about Being,

it doesn't mean that they were the only peoples

who ever had an essential asking.

Perhaps the terms are not precisely the same.

The question of Being, however, occurs naturally in every human being due to the mere fact that everyone has to deal with things (being).

There cannot be a society that, being there in the world, doesn't wonder

about the foundations of reality, about that what animates everything that is, about the reason of being of every being.

\section{The Research Method}

Between facticity and transcendentality, whether the dialectical method, or the analytical method, or the phenomenological method,

or the hermeneutic method

(presented by Ramón Rodríguez in his anthology of Methods of Ontological Thinking) ${ }^{10}$, I prefer to be against any method

If by "method" is meant the rule of objective

(logical-scientific) rationality.

The path we have followed

$$
\text { à la Latin American }
$$

starts with corporal experience, with material experience, with the affective-sentimental attitude

of feeling the feet on the ground.

To feel ourselves one with each other, palpating us naturally, affectionately, spiritually:

brothers and sisters of the stone, the river, the tree,

Journal of World Philosophies 2 (Summer 2017): 12-27 Copyright (C) 2017 Juan Cepeda H.

e-ISSN: 2474-1795 • http://scholarworks.iu.edu/iupjournals/index.php/jwp• doi: 10.2979/jourworlphil.2.1.02 
the air, the thunder, the huacasii and the spirits,

the mountains and the skies,

starting from that natural interconnection

of one with each other

and everyone to everyone,

under the horizon of

sensing sensitivity

which, as a starting point,

is basic and fundamental, irreplaceable.

There is as well in this starting point

some rational interpretation,

which offers certain explanations

also from some

culturally imposed logic given beforehand.

This requires some deconstruction

of the various rationalities

that originate in our horizons of interpretation

when we believe we know the world objectively.

The proper use of reason, of course, is necessary

but not in a naive way:

we have to do an exercise of explication

of the logical apparatus

with which any possibility of understanding

is manipulated, consciously or unconsciously, behind every rationality.

But without the stubbornness of those who do not want to hear

ancestral wisdom,

it is just as necessary

to be attentive to the voice of the spirit,

to the strength of the divine,

which always comes to complement

every personal effort

when we approach the essence of things,

the very Being of the total

reality.

No need to say

That the spirit shows itself precisely

ii A buaca is a sacred place/character, a material spirit who takes care of the place, an existential testimony of divinity (Translator's note).

Journal of World Philosophies 2 (Summer 2017): 12-27

Copyright (C) 2017 Juan Cepeda H.

e-ISSN: 2474-1795 • http://scholarworks.iu.edu/iupjournals/index.php/jwp• doi: 10.2979/jourworlphil.2.1.02 
combining the various possibilities of reality:

corporal,

psycho-intellectual,

mythical-mystical...

corporal-emotional-spiritual.

To discover the path to follow,

and thereby step in a path that does not close

the various possibilities that reality itself offers to us,

we have to sentipensarii the fire:

What a tautology!

Is it possible to feel the fire and not to think about it at all?

But there are those who are solely dedicated to think of it

because they fear to be burned!

To feel the whole reality: to do mambeo with her,

to speak it by the hearth,

to seduce it in words

and verbalize it in emotions, shared,

gifted, offered, embodied.

The ontological sentipensar,

as a research method,

requires the non-pretentious facticity

of the encounter with others,

listening

next to the fire,

learning with humility

from the indigenous, the farmer,

the taita, iv the grandfather,

the popular wisdom,

paying attention respectfully to their saying

just as respectfully as we read a scientific paper, without despising,

without that rude lust of he who believes

he is the holder of the objective truth, of he who blindly believes that the whole truth

is in the small scientific truth.

iii Sentipensar is a verb composed of the verbs "feel" (sentir) and "think" (pensar). It is both to think with feeling and feel with thinking (Translator's note).

iv The traditional male authority in native indigenous peoples (Translator's note).

Journal of World Philosophies 2 (Summer 2017): 12-27

Copyright (C) 2017 Juan Cepeda H.

e-ISSN: 2474-1795・http://scholarworks.iu.edu/iupjournals/index.php/jwp• doi: 10.2979/jourworlphil.2.1.02 
The practices of conversation

with all their simplicity and jocularity,

with all their wisdom and seriousness,

evidence the starting point

of a fraternal, humble, deep

research method

out of which a solid wisdom comes

and distills true, vital, quotidian, necessary wisdom.

That is how grandmothers and taitas

weave, instead of knowledge, existential wisdom nourished by

the essence of everything that is, by a warm and affectionate reason, which offers the possibility of meaning from the daily Being, enriching both the most specific chores and the most spiritual reflections...

\section{$4 \quad$ A First Notion}

In the shagra, ${ }^{v}$ each seed emerges from the depths of the soil with a certain strength that makes it germinate.

There couldn't be another way.

In the burner, the fire remains upright with a certain strength that prevails with its light and heat.

It has been always that way.

In the storm, the thunder does not only come with physical strength

and gets right into the midst of us leaving no chance to flee neither from the thunder, nor from the lightning.

When we put pressure on a tree, or a stone,

Shagra is a traditional indigenous or rural garden that serves as familiar source of food and whose caregivers are not only the farmers but also gods and spirits (Translator's note).

Journal of World Philosophies 2 (Summer 2017): 12-27 Copyright (C) 2017 Juan Cepeda H.

e-ISSN: 2474-1795 • http://scholarworks.iu.edu/iupjournals/index.php/jwp• doi: 10.2979/jourworlphil.2.1.02 
or when we hear a truth, or feel a true feeling,

they are all imposed on us by a strength

that makes them undoubted.

There can be no doubt.

Everything that is

is made up of strength.

And not merely physical strength.

Our first glimpse

of the Being

is found in its strength.

There is strength in the river

And there is strength in the sea.

There is strength in the ceiba and there is strength in the orchid.

There is strength in the jaguar and there is strength in the condor.

There is strength in the hummingbird and there is strength in the human being.

There is strength in the thought and there is strength in the speech.

There is strength in the myth and there is strength in the miracle.

There is strength in the life and there is strength in the spirit.

Strength is everything that is: Being is strength, mere effort, that is it!

The Latin American ontology gives its first step, then, with certain aesthetics of effort, an aesthetics of strength, says Carlos A. Moreno ${ }^{11}$. The poet Porfirio Barba Jacob had already sensed it in its judgment:

"to live is to strive"12.

An effort to listen to everything that is,

Journal of World Philosophies 2 (Summer 2017): 12-27 Copyright (C) 2017 Juan Cepeda H.

e-ISSN: 2474-1795 • http://scholarworks.iu.edu/iupjournals/index.php/jwp• doi: 10.2979/jourworlphil.2.1.02 
attentive and respectfully, according to ancestral practices of the various indigenous peoples.

An effort to be present, steadfast, such as the descendants of African peoples, brought to our lands forcibly and contemptibly.

An effort to bury the plough and urge on the oxen, to know how to sow the seed and care for the harvest, and to be patient to wait for the fruit, whose example the farmers teach us, year after year.

And also a daily and humble effort by the women who, in the neighborhood, wash clothes, clean floors,

by the sweat of their brow, of their life, to have means to feed their children.

This may be a populist effort (according to the academics who sitting in mighty desktops know how to argue their ideas and practices), but it is a real, existential effort, truly embodied, it is not mere abstractions rationally developed to be written in publishable texts, and nothing else!

Our first notion is a sensing notion that beats, that hurts, that knows our history and the truth of our existence.

Just as birth: no pain, no birth. 


\author{
Being \\ is strength, \\ mere \\ effort, \\ and nothing else.
}

\title{
5 The Melody of the Concept
}

Every word has its music.

Every statement has its melody.

But what is said

does not have a rhythm of its own

just because of being a word, a statement, but because it expresses the reality

that produces that melody.

One must be able to listen, to make silence,

in order to chat with the things

and understand their own rhythm, their musicality.

Every word has its music, which is the music of the verbalized.

Music of truth.

True music.

When asking for the Being

a smart effort is needed

to capture the pace of every single thing, of the total reality, of everything that is.

When asking for the Being and attending to it with simplicity, you start to perceive its melody:

The total

Being

is a symphony

formed

by the pace that the stone keeps in its heart, by the pace that the river croons in its flow, by the pace that the tree cracks in its soul,

Journal of World Philosophies 2 (Summer 2017): 12-27 Copyright (C) 2017 Juan Cepeda H.

e-ISSN: 2474-1795 • http://scholarworks.iu.edu/iupjournals/index.php/jwp• doi: 10.2979/jourworlphil.2.1.02 
by the own pace of all animals, by all those paces invented by all human beings, and the pace of angels, deities and gods, which at every step walk with us and watch over our actions,

but also by all the paces

of each and every one of the chemical elements, and each and every one of the planets, and stars, and constellations, of all the possible universes, and the sky's as well as the earth's paces, and, yes, also, including the silences all of them, without losing any, including the pace of nothing.

Then, and only then, what is heard in the heart?

Being

is

rhythmical strength.

It is just that, nothing else:

rhyth-

mi-

cal strength...

Everything that is is its melody, the melody of what it is.

Everything that is is verbalized, not with mere words

but with the pace of that what is being.

The essence of the concepts is not in the mere logic of its argumentation 
but in the musical truth that they suggest.

We must learn to listen.

We must learn to feel.

To feel:

the soul of things, the touch of words, the pace of essence, the symphony of the total Being.

When our elders, our taitas and grandparents, do mambeo, when our grandmothers, mothers and women talk

next to the hearth, they spin, weave, taste, dance sensing concepts

in which an existential wisdom becomes concrete.

The genus and specific difference is nothing but a formality that can wisely be left aside.

The essential condition of concepts is their musicality: the intrinsic rhythm that nourishes it, that feeds it, that vivifies it and makes it say what-it-is.

That is why the understanding of being requires a very particular attitude, perhaps one of the most demanding for the human being.

It is not only about the mind, 


\author{
unless it is \\ in the whole body... \\ and is conceived also spiritually, \\ as explained by Francisco Varela ${ }^{13}$. \\ The symphony of Being, \\ already perceived by José Vasconcelos \\ in his Treaty on Metaphysics ${ }^{14}$, \\ requires proper acoustics
}

in order to listen to its entire musical complexity,

to sense it in its entire natural

rhythmics.

. 2.8 .9

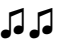

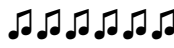

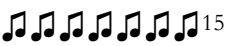

6

Vital Sense

So, what is the sense of the Being?

What is the sense of being?

Where does everything that is points at?

Being is seed.

The ontological sense is the life.

Life.

Germ.

Vital-origin.

Vital sense.

The whole-total-

Being

is the cradle of life;

its whole sense

offers the vital

raison d'être.

Journal of World Philosophies 2 (Summer 2017): 12-27

Copyright (C) 2017 Juan Cepeda H.

e-ISSN: 2474-1795 • http://scholarworks.iu.edu/iupjournals/index.php/jwp• doi: 10.2979/jourworlphil.2.1.02 
What is everything that is for,

If there is no life?

Life is there!

Life is there

because there is Being.

Being and life

come together

being

vitally made.

The universe as a whole

-with all of its universes-

has fixed on life.

There you have its meaning:

ontological sense,

vital sense.

Being

is a rhythmical,

autopoietic,

total

strength...

Life emerges from everything that is, it feeds from Being

and nourishes Being.

Life is the act of being,

nanovitally

constituted

and spiritually

oriented.

The ontological autopoiesis

puts down its roots in Being

and offers him its entire sense:

ontological sense,

which is vital sense.

Between the Muiscas

there was the ancestral tradition of

Gué,

vital ontological principle

infinitely giver of Being,

Journal of World Philosophies 2 (Summer 2017): 12-27

Copyright (C) 2017 Juan Cepeda H.

e-ISSN: 2474-1795 • http://scholarworks.iu.edu/iupjournals/index.php/jwp• doi: 10.2979/jourworlphil.2.1.02 
personified in Chiminigagua, the primary deity

which creates from the heart everything that is.

That is why the nature of sentipensar

requires a connection from the heart

with nature as a whole;

understanding the cosmos

with all its meanings and senses

implies not a pure and simple reasoning

—only reasoning-

But a reasoning-with

(with-everything-that-is and with-the-heart), that is to say: to co-reason:

$$
\text { corazonari. }
$$

To understand is corazonar.

To learn is to sharpen the ear until you hear clearly the heart of the cosmos.

To know is to sink into the heartbeat of nature.

You only understand while you are being.

To understand is to be one with the other, one with others.

We are brothers and sisters with the river and the sea, with the ceiba and the orchid, with the jaguar and the condor, with the hummingbird and the spirit.

The whole life connected with everything that is.

The whole being vitally understood.

This is the first wisdom

discerned by Latin American philosophy, a philosophy which knows how to listen to ancestral wisdom and which talks to the people,

feeding thereby not only on cultured and pure traditions

but-also- on the stench of geo-culture

typical of the simple, the small, and the humble ones, habitually collected by word of mouth for centuries.

vi It is a play on words trying to resemble "co-reason" with the Spanish word for "heart": corazón. It is also related to the word corazonada (in English "hunch") (Translator's note). 
Juan Cepeda H. is doing his doctorate at the Universidad Santo Tomás (Colombia). The topic of his dissertation is 'The Ontology of Rudolf Kush.' He is director of the Tlamatinime Research Group on Latin American Ontology, and SEmillero MEtaphysics and ONtology (SEMEyON). Cepeda leads the Ch@ski: International Network of Ontology Researchers. For more information, see the micro-site he maintains at the Universidad Santo Tomás (http://ontologia.usta.edu.co). Cepeda works on the ontological sentipensar.

1 Juan Bautista Alberdi, "Ideas para un curso de filosofía contemporánea," in Fuentes de la cultura latinoamericana, ed. Leopoldo Zea (México: Fondo de Cultura Económica, 1995), 143-51.

Véase particularmente Enrique Dussel, Politica de la liberación. Historia mundial y crítica (Madrid: Trotta, 2007); Política de la liberación II. Arquitectónica (Madrid: Trotta, 2009); Ética de la liberación en la edad de la globalización y de la exclusión (Madrid: Trotta, 2011).

3 Mario Mejía Huamán, Anti yachay wayllukuy. Filosofía andina (Lima: Universidad Ricardo Palma, 2011); Josef Estermann, Filosofía andina. Sabiduría indigena para un mundo nuevo (La Paz: ISEAT, 2006); Flores Quelopana, G., Los amautas filósofos (Lima: Instituto de Investigación para la paz, 2006); Juan Cepeda H., Ontología indigena. Aproximación filosófica a saberes filosóficos que posibilitan una ontología latinoamericana (Rosario, Argentina: Ross, 2013), 15-42; Guiovany Púa, Filosofías amerindias: búsquedas de lo propio en América Latina (Bogotá: Universidad San Buenaventura, 2011). Raúl Fornet Betancourt, Transformación intercultural de la filosofía (Bilbao: Descée, 2001); Dina Picotti, Una propuesta interlógica ante los desafios del pensar contemporáneo (Buenos Aires: Universidad Nacional de General Sarmiento, 2010), 61.

5 Darío Botero Uribe, Vitalismo cósmico (Bogotá: Corteza de Roble, 2007); Damián Pachón Soto, Preludios filosóficos a "otro mundo posible" (Bogotá: Desde Abajo, 2013).

6 Mauricio Beuchot, Hermenéutica analógica. Aplicaciones en América Latina (Bogotá: El Búho, 2003).

$7 \quad$ Rodolfo Kusch, La negación en el pensamiento popular (Buenos Aires: Las Cuarenta, 2008).

8 Juan Cepeda H., Sentipensar ontológico [Texto inédito del curso seminario dictado en la Maestría en Filosofía Latinoamericana] (Bogotá: Universidad Santo Tomás, 2015).

9 SEmillero MEtafísica y ONtología: SEMEyON. A lo profundo de Kusch. Tras una ontología latinoamericana (Bogotá: Nueva América/Tlamatinime, 2013).

10 ed. R. Rodríguez, Métodos del pensamiento ontológico (Madrid: Síntesis, 1996).

11 Carlos Moreno, Los conceptos griegos de Ser y tiempo. Aproximación al pensar ontológico de Heidegger (Bogotá: Universidad Santo Tomás, 2012).

12 Porfirio Barba Jacob, La divina tragedia. En: Poesías (Bogotá: Círculo de Lectores, 1984), 45.

13 Francisco Varela, En: El fenómeno de la vida (Santiago de Chile: Dolmen, 2002), 149-365.

14 José Vasconcelos, Tratado de Metafísica (México: México Joven, 1929).

15 Juan Cepeda H., Ontología desde la música andina. En: Tras del sentido del ser. Aproximaciones a una ontología en perspectiva latinoamericana (Saarbrücken: Editorial Académica Española, 2011), 77-104.

Journal of World Philosophies 2 (Summer 2017): 12-27

Copyright (C) 2017 Juan Cepeda H.

e-ISSN: 2474-1795 • http://scholarworks.iu.edu/iupjournals/index.php/jwp• doi: 10.2979/jourworlphil.2.1.02 